\title{
Durkheim, DeVelopment AND the Devil: A Cultural Sociology of Com- MUNITY CONFLICT
}

\author{
MERVYN HORGAN
}

\begin{abstract}
Durkheim's The Elementary Forms of Religious Life provides a theory of the eminently social processes by which people, places, times and things come to be seen as sacred or profane. He demonstrates how the sacred is a locus of collectivization essential to the formation of the solidaristic bonds that characterize a moral community. Recent work in cultural sociology suggests that the mobilization of the binary discourse of civil society — the sacred/profane - is key to democratic deliberation in the public sphere (Alexander 2006). Drawing on participant observation, local media resources, and printed and online materials, this paper examines the deployment of this binary discourse in a conflict around the rezoning of agricultural land in rural Nova Scotia (2009-2011). Substantively, this case demonstrates how the symbolic coding of rural/agricultural space as sacred played a significant role in the rejection of the proposed rezoning. At a theoretical level, this paper reaffirms that the Durkheimian vision of the symbolic power of the sacred remains a core cultural resource in social organization and political mobilization, and a vital conceptual resource in sociological analysis.
\end{abstract}

Keywords: sacred/profane; solidarity; civil society; rural space

Résume: Dans Les formes élémentaires de la vie religieuse, Durkheim délivre une théorie des processus éminemment sociaux par lesquels la société, l'espace, le temps et les objets finissent par être perçus comme sacrés ou profanes. Il démontre comment le sacré est un locus de collectivisation essentiel à la formation de liens de solidarité qui caractérisent une communauté morale. Des travaux récents en sociologie culturelle suggèrent que la mobilisation du discours binaire de la société civile_-le sacré/profane — est la clé de du debat démocratique dans la sphère publique (Alexander 2006). À partir de l'observation des participants, des ressources médiatiques locales, et de documents imprimés et en ligne, cet article examine le déploiement de ce discours binaire dans un conflit concernant le rezonage des terres agricoles dans les régions rurales de la Nouvelle-Écosse (2009-2011). En substance, cet exemple démontre comment l'encodage symbolique de l'espace rural/agricole comme sacré a joué un rôle considérable dans le rejet de la proposition de rezonage. Sur le plan théorique, cet article réaffirme 
que la vision durkeimienne du pouvoir symbolique du sacré reste une ressource culturelle centrale dans l'organisation sociale et la mobilisation politique, et une ressource conceptuelle vitale en analyse sociologique.

Mots clés: sacré/profane; solidarité; société civile; l'espace rural

\section{INTRODUCTION}

Kiss Goodbye to a broad expanse of 380 acres of productive farmland... Kiss Goodbye to [the town] we all know and love: a lovely, little and quiet, self-contained valley town bordered by rolling hills and farm fields stretching to blue sky and sea... Kiss Hello to paying up to $\$ 54$ million in additional taxes to finance all the infrastructure needed to make life easy for the developers... Kiss Hello to the relentless noise and traffic that comes with living in the embrace of a development zone open to widescale commercial, industrial and residential sprawl.

$\int \mathrm{Nor}$ his was the text of a flyer circulated to residents of a small town in Nova Scotia by a local group named "No Farms, No Food." The flyer was intended to recruit opposition to a development proposal submitted to the local municipality by four local farmers and a garden nursery owner seeking to rezone their farmland for a range of "residential, commercial and urban agricultural land uses" (Municipality of the County of Kings 2010: 1). By juxtaposing a rural idyll, a Garden of Eden, with the apparent evils of dense development more generally associated with capitalist urbanization, the flyer clearly sought to rouse community ire. To this end, it provided information about an upcoming presentation by the local county council on the proposal, and a community strategy session where diffuse but simmering discontent could be collectively channelled and an organized opposition formed.

While the conception of the sacred found in Durkheim's (1995 [1912]) The Elementary Forms of Religious Life (hereafter, EFRL) deals directly with religious faith and practice (beliefs and rites), when we think of applications in the world of politics, the rural municipal planning scene is unlikely to be the first thing that pops into our heads. Examples are more likely to be drawn from more readily available forms of symbolic action, like collective rituals that appear to embody and express the ideals of the nation, or from figures like charismatic leaders, rather than the admittedly mostly mundane world of planning and politics in rural municipalities. Scholars drawing on EFRL tend then, towards case studies, examples, and illustrations that operate at the national or international scale. At this scale EFRL appears in studies ranging from the 
place collective effervescence in the fall of the Berlin Wall (Tiryakian $1995)$ to the part played by commemoration in patriotic sentiment in the US (Schwartz 1991) and the prospects of global democracy (Cladis 2005). The ready applicability of ideas from EFRL at the national and international scale does not diminish their potential conceptual utility at a smaller one. That said, scholars appear to have shied away from thinking with Durkheim at this more local scale. As this paper demonstrates, a century on, EFRL provides us with a conceptual toolkit well suited to understanding a local conflict over zoning in one small corner of contemporary eastern Canada. Following on contemporary usage of a Durkheimian conception of the sacred in cultural sociology (Alexander \& Smith 2001; Alexander 2006), I treat civil society as the staging ground for contestation around the sacred. This paper will show how, viewed through this lens, we find in EFRL a means for analyzing the source and the course of conflict over the proposed rezoning of agricultural land in rural Nova Scotia, and the "how and why" of successful mobilization against the proposed rezoning.

I begin by outlining Durkheim's conception of the sacred as developed in $E F R L$, focusing in particular on the role played by the sacred in the formation of moral communities. Following from recent work in cultural sociology, I treat the sacred/profane as the organizing binary in the discourse of civil society (Alexander 2006). From there I offer a brief summary of literature on conflict over land use in rural communities to provide context for the case study of a conflict over agricultural land in Nova Scotia. I amplify details of the case study through theoretical analysis focused on the centrality of the sacred and, in particular, beliefs and rites, for the constitution and operation of symbolic power. In the conclusion I make some observations about the relationship between the sanctification of the "local" and the possibilities for the expansion of social solidarity in Canada and beyond.

\section{Durkheim's Theory of The SACRed}

For Durkheim, the sacred is a central organizing element of social life (EFRL: 33-44, 207-216). Early in EFRL we find Durkheim reiterating again and again that sacredness is not something that is immediately apparent or available to sensory experience. As he notes, "[a] rock, a tree, a spring, a pebble, a piece of wood, a house, in a word anything, can be sacred" (ibid.: 35). Nothing is inherently sacred. Rather, something becomes sacred by virtue of the orientations of actors to it and the social relations that organize around it. Durkheim gives the sacred a vital place 
in religion, and while this is the focus of $E F R L$, analytic extension of the concept to social organization in other realms of collective life is clearly valuable. The sacred both connects actors to one another and forms the basis for solidary ties more generally.

The sacred cannot be considered independently of the profane. For Durkheim, the heterogeneity of the sacred and the profane is absolute. To emphasize this point he states, "[i]n the history of human thought, there is no other example of two categories of things as profoundly differentiated or as radically opposed to one another... the sacred and the profane are always and everywhere conceived by the human intellect as separate genera, as two worlds with nothing in common" (EFRL: 36). Rather than being defined by inherent characteristics of the objects to which they attach, the sacred and the profane are defined in opposition to one another. In EFRL, this "radical duality" (ibid.: 39 ) organizes religious beliefs and rites. As Pickering notes, "Durkheim sees the sacred-profane dichotomy not just as a descriptive term, but as a causal factor in understanding social life" (1984: 162). Durkheim himself asserts that this binary prevails across social contexts: "while the forms of the contrast [between sacred and profane] are variable, the fact of it is universal" (EFRL: 36). ${ }^{1}$

A collective congregates (rather than merely aggregates) around a common conception of what is sacred. Durkheim calls such a collective a "Church" or a "moral community" (ibid.: 42). Moral communities form, cohere and mobilize not only around shared orientations to the treatment of sacred objects, but more significantly for us here, around shared conceptions of what is sacred. The sacred is a shared point of reference for the group and symbolizes the group to itself. For a moral community, collective action is inspired by that sacred. Action alone though, does not constitute the social, for, the interpretation of action, too, is constitutive. Interpretation is not simply an autonomous activity engaged in by freefloating actors (Durkheim 1974: 1-35). Rather, interpretations of action are more or less compelling, they are more or less consistent, they find confluence with other acts and interpretations, fitting into broader meaning systems and collective representations that provide them with more or less coherence (EFRL: 38-39). Thus, the meanings of the sacred cannot be viewed as wholly derived from, or reducible to the local context of action (Durkheim 1960: 325-340; Geertz 1973; Reed 2011: 89-121). For Durkheim, the symbolic codes that animate and organize collective representations do not align perfectly with material conditions or economic interests. Rather, collective representations can be analyzed

1. Durkheim's assertion that the "fact" of the sacred is universal has been widely criticised, most famously by Goody (1961). 
as "partially autonomous realities" (Durkheim 1974: 31). ${ }^{2}$ It follows, then, that the affinities between various collective representations provide them with a coherence that can be analyzed independently of other spheres of collective life like politics, economy, and intimate relations.

Extending Durkheim's conception of the sacred as a solidarizing force and tethering the binary system that it rests upon to the operations of democratic discourse, Alexander (2006: 54-64) argues that the binary discourse of civil society is bound to the sacred/profane dichotomy. Where Durkheim's use of the sacred/profane dichotomy helps us understand the development of solidarity, EFRL is largely silent on the part played by the sacred in group fissures and conflict. ${ }^{3}$ This is not to say that Durkheim cannot help us to understand intra-group conflict. So, to extend Durkheim's ideas into this territory I draw upon Alexander's work on the binary discourse of civil society. For Alexander, the binary discourse of civil society is a

highly generalized symbolic system that divides civic virtue from civic vice in a remarkably stable and consistent way. It is for this reason that, despite divergent historical roots and variations in national elaborations, the language that forms the cultural core of civil society can be isolated as a general structure and studied empirically as a relatively autonomous symbolic form (2000: 299).

When we examine both the things that are taken to be sacred and the ways in which they come to be articulated as sacred, we learn something about the social organization of particular locales and nations. In particular, we learn how bonds of solidarity are intensified or broken, and extended or restricted. Below, I examine how opponents to the rezoning of agricultural land noted above, activate binary discourses — of the civil and the uncivil, truth and deceit, transparency and secrecy — structured around the relatively elementary sacred/profane dichotomy. In short, the binary discourse of civil society — as used in contemporary cultural sociology — is structured in a manner homologous with that obtaining between the sacred and profane as analyzed in EFRL. In cultural sociology, drawing on and extending Durkheim's insights in EFRL, the sacred

2. While Durkheim makes this claim in his earlier work (see especially 1974, 1-35), it is worked out most comprehensively in EFRL.

3. One notable exception is Durkheim's brief discussion of scapegoating ( $E F R L$ : 404). 
appears in two ways: as a cultural resource in social and political mobilization; and as a conceptual tool for the analysis of collective life. ${ }^{4}$

Through Durkheim's work we understand that systems of meaning have a relatively consistent structure across contexts, thus providing coherence to action and its interpretation. Collective representations spring from social processes embedded in specific contexts (EFRL: 226-230). Collective representations condense both meanings and interpretations, thus providing conduits for collective action. The binary discourse of civil society provides a resource for actors, and gives structure to actions and interpretations.

Enlivening concepts by embedding them in particular places provides for more textured understanding. This means examining how local-level reasoning and exigencies find confluence with and draw upon broader structures of meaning. Where many cultural sociological applications of Durkheim deal with civil society on the national-historical scale (Baiocchi 2006; Jacobs 2000; Ku 1999; Smith 2005), here I examine their applicability in a local rural context, on a piece of land on Canada's east coast, by focusing on the following questions: How does the binary discourse of civil society operate when brought down to this scale? How is the symbolic power that adheres to the sacred and profane activated and put to work in what appears to be a relatively straightforward battle over zoning?

Having outlined the wider theoretical context of this paper in relation to Durkheim and Alexander's cultural sociology, I now move towards the case study, first by briefly outlining relevant work on rurality and development, and then by sketching out a profile of the community where the conflict takes place.

\section{Rural Space, Conflict and Development: A Case Study of GreEnwich, Nova Scotia}

Studies of contentious issues in municipal politics tend to focus primarily on urban contexts (Crowley 2005; Elkin 1985). This case study concerns an area of low density, one that does not meet any technical definition of the urban. Literature on development in rural areas tends to focus

4. It is important to note that in this paper I work with a more limited conceptualization of the sacred than that developed in EFRL. In line with more conventional usage in cultural sociology, the left and right sacred as distinguished by Durkheim are largely backgrounded (see Riley 2005). Primacy is instead given to the mobilization and organization of cultural power in and through democratic discourse organized around the radical heterogeneity of the sacred and profane. 
on environmental history (Rome 2001) and on movements against urban sprawl in particular locales (Logan 1995; Mason 1992). Many postwar studies of suburbanization and rural residential development read primarily as laments for what may be lost in the wake of development (Lillard 1966; Whyte 1968). The rural-urban binary is foregrounded across this literature. In sociology more broadly, this binary appears variously as a tool for ideal-typical analyses of assorted forms of social organization, as a description of different ways of life, and as a way to designate differing moral worlds (Bonner 1997; Durkheim 1964; Pahl 1966; Tönnies 2002; Williams 1985). ${ }^{5}$

A Durkheimian approach needs, first and foremost, to understand the operation of some conception of the sacred in discussions of rural space. This sort of work barely exists in the literature. In a brief study of over a century of news reporting on drought in rural Australia, West and Smith show how the rural-urban distinction operates as a "normatively enforced myth" consolidated through "constant discursive intensification" (1996: 94), where "the leitmotif of calls for moral unity often takes the form of attacks on the decadence and irresponsibility of the city in comparison to the thrift and suffering of the country" (95-6). Oriented more explicitly to the battle for space, Sibley (1997) examines how asserting that rural space is sacred operates as a discursive strategy and a symbolic means for excluding certain populations in rural England. As an organizing binary then, discourses of the rural/urban are sometimes layered on top of - but not necessarily fixed to - those of the sacred/ profane.

In order to investigate the ways that power inheres in and adheres to particular representations of the rural in specific locales, I will turn now to our case study. I will first sketch a brief portrait of the area before delving into the details of the conflict.

Greenwich is a small hamlet located in the Annapolis Valley which, for Atlantic Canada at least, is a relatively dense settlement stretching for over 100 kilometres in western Nova Scotia. Most settlement in the Valley is organized around the now-defunct railway line and Highway 1,

5. Dwelling on either side of this binary can lend itself towards oppositional identification, so that the country becomes everything that the city is not (Horgan 2004), while the status of the suburbs is somewhat more ambiguous (Corcoran 2010). In the Canadian context, the Maritimes have long been associated with a rural ideal that meshes well with elements of collective representations of Canada more generally (Keohane 1997). That said, the Maritime iteration is also somewhat distinct. For example, in Nova Scotia, the claim to a rural ideal is highly sentimentalized and pervasively commercialized in tourist advertising. The genesis and course of this claim has been carefully scrutinized, historicized and deconstructed by McKay (1994). 
which was the principal route through the Valley until the construction of a major highway in the 1980s and 1990s. The Valley is predominantly agricultural and traverses three counties, a sizable portion in Kings County, which, with its large amount of productive farmland, is considered to be the food basket of Nova Scotia. Greenwich, located in Kings County, is located between the towns of Wolfville and New Minas. Wolfville is a small university town of over 4000 inhabitants, whose population rises to over 7000 during the academic year. New Minas (population c. 4500) was until the late 1960s simply farmland, but is now the shopping centre for the County, with the fairly rapid development of a two kilometre strip of mostly big box stores more akin to stereotypical North American suburban sprawl than to the more picturesque images associated with rural Nova Scotia. Between Wolfville and New Minas lies Greenwich, a community with roughly 300 residents, surrounded on all sides by farmland.

While Greenwich is not a town in the sense of having a clearly defined commercial or civic centre, there are a small number of businesses and non-residential buildings, so small that it is possible to offer a comprehensive inventory without testing the reader's patience. In addition to the five farm markets zoned "agricultural commercial" — four of which are adjacent to working fruit and vegetable farms - that make Greenwich the farm market capital of the province, other businesses include a honey producer, a tool hire business, a gas station, a used car dealership, various trades people, a recycling depot, a sod business, a small number of home-based enterprises and some "agricultural entertainment" uses (consisting of a small seasonal petting farm and something called "farmer's golf"). There is also a fire hall and a church. Housing consists of a number of older farm houses, some dating to the eighteenth century, a range of newer mostly one-off housing units, and a few small subdivisions added over the last thirty or so years. Besides a highway access road and one small rural road, there are no other non-terminal arteries off the highway. Agriculture is dominant, most of it in market gardening, and many fields remain fallow.

Faced with the declining prospects for relatively small-scale production in the wake of the continued industrialization of agriculture and the ever-dwindling prices that they can command for their produce in the face of cheaper imports, a group of local farmers claim that they can no longer make a living from farming. In 2008, four farmers attempted to have their agricultural land annexed to the adjacent town of Wolfville, so that their land value might increase by making it available for residential, commercial and institutional uses. This proposal failed to gain traction, but soon after, in 2010, joined by a local nursery owner, these farmers submitted a new rezoning proposal to Kings County Council. 
The proposed rezoning would take 382 acres of land currently zoned agricultural, and put it to other uses, both commercial and residential, as well as creating a new urban agricultural zoning designation (Municipality of the County of Kings (MCK) 2010a: 9). This designation would encourage "smaller, individual home, market garden, collective garden, organic and agri-tourism uses" (MCK 2010b: 7). No intensive livestock would be permitted, but small numbers of animals for personal use would. While it conformed to basic planning requirements around environmental easements with provisions made for the preservation of the best soils, and streams and ponds, the scale of the proposal was large for the area.

The proposed rezoning, which The Municipal Council of the County of Kings accepted at the first stage as the Greenwich Comprehensive Development District Plan (GCDD) unleashed a local social movement on a scale and level of organization that was unprecedented for the area. Details of the plan itself are secondary to the calls for its rejection. Here I treat the conflict as one where the discourse of civil society is enlivened, directing both collective action and, eventually, political decision-making. Central to this discourse is the expression and mobilization of discourses by activists in local media, online materials and public meetings, that can be helpfully re-described, analyzed and explained by drawing on Durkheim's conception of the sacred-profane relation. Local newspaper articles comprised an especially useful data set, as it was possible to access every local newspaper article on the rezoning, including straight news reporting, opinion pieces and letters to the editor. This data is supplemented by promotional materials produced by advocates and opponents of the rezoning, and participant observation through attendance at public meetings and open fora about the proposed rezoning.

\section{Making and Mobilizing a Moral Community}

Any understanding of civil society at the local scale requires that we look at when, where, how and why actors come together to discuss, argue about, and assert their positions and visions for the place in which they live. Beliefs and assertions about what is good or bad for the area are expressed in local media and in materials produced by groups with varying degrees of formal organization that intervene in the debate. As the space where claims about what is sacred are made publicly, arguments are most heated in the ritualized setting of public meetings where rezoning is discussed. Solidarity amongst opponents of the rezoning is at its most intense at rallies and events aimed at highlighting what is at stake. 
It is in and through these media and spaces that the sacred is most clearly articulated.

What, then, is the sacred around which solidarity is developed, harnessed and mobilized? How do individual and collective actors draw upon the binary discourse of civil society to make their claims, to bolster support, and to assert their unquestionable alignment with the sacred? At base, the battle was organized around two mutually exclusive groups: on one side, the farmers who wanted to rezone their land and their supporters, and on the other, community members (including many farmers) who did not want the land to be rezoned. Thus rendered, the differences seem straightforward: a basic conflict over a key resource, relatively transparent, requiring little but the most basic tools of sociological analysis. When battles over land use are tethered to the binary discourse of civil society, the structure of the discourse may be elementary, but use of the binary discourse is by no means simple. Here, the sacred is not something fixed nor is it a floating signifier that can be used at will by anyone; rather, each side attempts to articulate particular visions of the sacred both to mobilize collective action and to influence political decisionmaking. Before using Durkheim to show how the sacred is made and mobilized by way of beliefs and rites, I will briefly introduce some of the parties in the conflict.

Opposition to the rezoning was loud and highly visible. Its main organizational form was a group called "No Farms No Food." In the space of four months in the summer of 2010, No Farms No Food issued regular press releases, and organized rallies, public meetings and strategy sessions that garnered substantial local media attention. As part of this media blitz, a fifteen second radio spot aired on local commercial radio. "Warning", said a serious male voice, with the sounds of heavy machinery and the loud "beep beep" of construction vehicles in reverse gear in the background, "Kings County Council wants to back out of promises to preserve our precious farmlands - help stop them." "County Council races headlong to rezone farmland" proclaimed a headline in the group's newsletter, the story accompanied by a picture of a two-level outhouse, with county councillors on top, defecating on voters below. Threats to the democratic process appear here to be rife, the sacred code of democracy profaned. Online promotional materials included a before and after diptych; on the left, an aerial picture of present-day Greenwich bearing the text "Greenwich Garden of Eden", on the right, "20 Years Later", an aerial photo that might have been downtown Manhattan superimposed on Eden. The development plan, the image suggested, would create an urban hell. 
On the other side were the farmers who sought to rezone their lands and their supporters. In response to the high profile media attention garnered by No Farms No Food, these farmers called themselves "No Growth No Future." They asserted the need for development in the area to diversify business opportunities and to steady the tide of out-migration that has plagued the area for generations. Compared to No Farms No Food, No Growth No Future seemed much less organized and much smaller in number. While the latter group was formed by those who proposed the rezoning, it was ultimately a brief flash in the pan that failed to gain more widespread support due to an incapacity to mobilize sufficiently compelling symbolic resources to turn the tide of opposition. No Farms No Food, on the other hand, enjoyed massive support locally, received provincial and regional media coverage, and was ultimately successful in its stated goals. Territorial aggregation does not automatically produce solidarity; contiguity in space alone does not collective sentiment make.

Significant here is that allegiance to one or the other side did not coalesce around geographical location or occupational homology. In the fight against rezoning, families descended from the Planters who arrived in the late eighteenth and early nineteenth century (after Le Grand Dérangement, the "Great Expulsion" of the Acadians in 1755), were joined by newcomers and young back-to-the-landers. While continuity of ownership is often a basis for power in a rural environment - especially when a relatively small number of Planter families still own large proportions of the richest agricultural land - in this case these families stood on both sides of the divide, thus undermining this source of traditional authority (Weber 1968). ${ }^{6}$ On other local issues these farmers can generally make successful claims to some moral authority, but this was not the case here.

Understanding the battle over rezoning as organized around the sacred means treating it as a moral and cultural battle, waged as much in civil society as in the local council chambers. This is not to say that rezoning is not a political, economic or legal issue, rather it is not only these things. ${ }^{7}$ All discourse in civil society is moral (or moralizing), thus, arguments must become moral if they are to succeed. Moral claims can be organized around principles, ideas, objects and people taken to be

6. Though beyond the remit of this paper, a Durkheimian analysis of the role of inheritance and private property would be interesting to explore here. See Durkheim (1992) and Ramp (2001: 96-97).

7. Because they tend to be materialist, more conventional analyses of zoning conflict (for example, Smith 1996) are under equipped for understanding the role of collective representations in organizing action. 
sacred. The constitution of a moral community, then, can be delineated by examining the production, maintenance and deployment of discourses of the sacred in civil society.

For Durkheim, two things are basic to the constitution of moral communities: beliefs and rites. Beliefs are "states of opinion", while rites are "particular modes of action" (EFRL: 34). Beliefs are based on an elementary classification of the world into the sacred and the profane: "beliefs are those representations that express the nature of sacred things and the relations they have with other sacred things or profane things" (ibid.: 38). Beliefs are not simply held by individuals, they must be articulated in ways that feed off and into the conscience collective, emphasizing and securing solidarity through articulation with the sacred side of the binary. Rites contain some element of sacredness (ibid.: 35) and involve "rules of conduct that prescribe how man [sic] must conduct himself with sacred things" (ibid.: 38). In the constitution of moral communities, both beliefs and rites must meaningfully and convincingly invoke the sacred in order to connect people to that sacred and to bind them together through it.

For my purposes here, iterations of belief occur in the domain of letters to the editor, claims made in promotional materials and speeches, and proclamations at public meetings. Rites too come in a variety of forms. Examples used here are those that form part of local decisionmaking processes in representative democracy; rites which are, in principle, open to all citizens such as the legally mandated Public Participation Meetings that follow any rezoning application. As elaborated below, a Durkheimian perspective on such meetings differs substantially from a more proceduralist orientation concerned with rational deliberation as the locus of democratic discourse (Habermas 1996). There are also other kinds of rites explicitly aimed at solidarizing, where, for example, a group professes collectively held beliefs to itself (and sometimes to the wider public), where those persons considered to be profane are actively excluded. Two examples are dealt with here very briefly: a local antirezoning strategy meeting and a rite which exhibits characteristics of piacular rites as dealt with by Durkheim (EFRL: 392-417).

\section{Beliefs and Binaries}

The most visible manifestation of No Farms No Food's organizing was the distribution of lawn signs in Greenwich and surrounding areas. The green and black signs bore the silhouette of a stylized farm with the simple text "SOS Save Our Farms" and a web address. They cropped up everywhere in the locality, on lawns and doorsteps, in the one farm 
market opposed to the rezoning, in the local vegetarian cafe and in two local fair trade organic coffee shops. No Farms No Food claimed to have distributed 500 such signs and the clearly visible presence of the sign in so many places made its absence in others all the more palpable. Late in the summer of 2010, at the height of the controversy and when the SOS signs were at their most ubiquitous, a proponent of the rezoning was arrested for uprooting several signs and throwing them down an embankment (KCA, August 3, 2010). ${ }^{8}$ This was a relatively minor incident that brought a local newspaper editorial to proclaim that calling this act "childish" would be unfair to our children. The arrest created space for the opponents of the rezoning to draw upon a binary discourse; letters to the editor characterized the farmers who proposed the rezoning as irrational, uncaring, as people who used the cover of night to pollute a waterway, and as people who did not respect property owners' rights and individual freedom of expression. The implicit contrast here is with opponents of the rezoning who are rational, caring, transparent, environmentally responsible, respectful and democratic. Beyond this specific incident, letters pages, editorials and general reporting in local media were dominated for months by the conflict.

There follows a very small selection of quotes to demonstrate various ways that a binary discourse was invoked. One report bore the headline "Save our souls - and farms too" and continued, "[t]here looks to be a civil war going on....important documents have been discussed by council in camera" (HJ, August 12, 2010). Soon after, "[a]lthough unannounced on its agenda for the October $5^{\text {th }}$ meeting of Kings County Council, rezoning got first reading for transforming Greenwich from a scenic, peaceful and successful rural farm market community into a sprawling development zone" (KCA October 12, 2010). This followed earlier claims that the local council had "established and strengthened an oligarchy" (KCR September 17, 2009). Controversy and concerns around violations of the sacred code of democracy (openness vs. secrecy) were present from the outset. Also invoked was the familiar ruralurban binary. "Protect it don't pave it" (KCA, February 1, 2011) ended one letter. Another claimed that the rezoning would suit "city dwellers who finally get the chance to build their monster house on a five-acre lot: one acre for the house, four for the lawn" (KCA January 25, 2011). Even more significantly, one letter writer noted that "these are very important matters that will affect us and our descendents for all time" (KCA June 29, 2010) and another asserted that "No Farms No Food folks are the sort

8. All local newspaper quotes are taken from the following weeklies: Kings County Advertiser (KCA), Kings County Register (KCR), and Hants Journal (HJ). 
who, when faced with injustice and greed, cannot lie down. Perhaps they see themselves as the last line of defence against the destruction of a way of life" (KCA November 16, 2010). ${ }^{9}$

Taken together these assertions clearly demonstrate an array of concerns around backroom dealing, exclusion from the democratic process, the environment, selfless sacrifice and not just the future, but eternity. As Pickering notes, "[w]hat is individual is profane: what is social is sacred" (1984: 154), and as such, these assertions work through an opposition between the individual and society, between the mere material interests of individual land owners in the short-term and the communally constituted ideals of the collective in the long-term. While the above claims are significant in their own right, they become even more pronounced when we turn to the democratic ritual of the Public Participation Meeting.

\section{Sacred Secular Rites: Democratic, Piacular}

Public Participation Meetings (PPMs) are essential to the transparent functioning of the local planning process. In most parts of Canada, PPMs are a legally mandated part of any application for rezoning or development. They are generally a matter of provincial jurisdiction, for example, in Nova Scotia the Municipal Government Act requires PPMs. More than this they are the fora for the expression of democratic ideals and a staging ground for the drama of local democracy; they provide for a ritualized and heavily circumscribed encounter between local leaders and local people, between bureaucratic machinations and the demos. These occur daily across the country and are generally procedural and mundane, but on occasion, they are fraught battlegrounds. In Greenwich, PPMs became incendiary. The first, held in June 2010, was attended by 75 people and received 80 written submissions. That meeting had been preceded by a "community strategy meeting" organized by No Farms No Food. A local councillor who was known to be in favour of the rezoning showed up to the strategy meeting and was cast out by those assembled before the meeting even began (KCA June 22, 2010).

On a cold November night in 2010, I attended the last of the PPMs required by law. Attendance had been steadily building at any sort of meeting about the proposed rezoning. I counted 199 people in attendance squeezed into the local fire/community hall; this, in a community of roughly 300 people. Generally PPMs have a very straightforward struc-

9. In a study of letters to the editor in US metropolitan newspapers, Perrin \& Vaisey (2008) found that letters on local issues tended to have a conciliatory and reasonable tone compared to letters dealing with issues beyond the local context. The brief selection offered above suggests that the opposite may be true in this case. 
ture, but this one was clearly different before it even began. As the meeting opened the local troupe of Raging Grannies approached the front of the hall and took over, singing a many-versed song about goodness and greed, health and illness, purity and pollution, the finale an emphatic last line proclaiming that, "the land must be held in trust." They were allowed to finish the song before the Chair spent 10 minutes extemporizing on the nature of respectful communication and the importance of listening, imploring participants to be considerate, to refrain from cheering, booing and hissing, and to allow whoever wants to speak to speak. Reverence for the process of local democratic deliberation, while expected, needed too to be requested and reasserted.

The first speaker - a local beekeeper concerned that the area would be covered in pavements, houses and lawns - wondered aloud how the "urban farms" would be pollinated. Things proceeded from there with long line ups at the microphone. Person after person stood and spoke, with the vast majority of speakers voicing strong opposition. The crowd was hushed and occasionally triumphant. A sprinkling of pro-rezoning speakers were met with a smattering of polite but muted applause and low-level murmuring, occasionally enlivened by two or three supporters clapping loudly and emphatically. That these supportive gestures were individually distinguishable made manifest their profane status relative to the indistinguishable collective cheers and jeers meeting anti-rezoning speakers. A description of events can hardly do justice to the extent to which this event gathered community sentiment and channelled it in a particular direction. The constant allegations of wrong-doing and violation of democratic principles were so powerful that at this meeting one had the palpable sense that a silent paymaster had indeed exerted some sort of authority to be mobilized in favour of the rezoning (accusations of this kind are entirely unsubstantiated). "If you do not answer to the people, then just who do you answer to?" proclaimed one opponent to huge cheers. The sanctity of the democratic process had been called into question, and so the moral case against rezoning could only build.

The familiar rural-urban binary was again a constant presence, with a dozen speakers warning against the perils of "urban encroachment." One contributor wanted to "stop the urban corridor at the border of New Minas, where it belongs", while others proclaimed that "subdivisions are not the answer", that they "left suburbia to get the frig out of there", and that "people who move here are escaping urban jungles." The urban appeared, over and over, as the profane foil to the sanctity of the rural; the urban was depicted as the locus of ruthless individual self-interest, the rural where collective sentiment still reigns. While many speakers drew on this familiar binary between the urban and the rural, not every- 
one's contributions focused on it. Several asserted that since the soil both grounds and nourishes the community, it is sacred: "we're sitting on a field of diamonds - apples, trees, grass"; "no land should be sold that is cultivable"; "what is more important to you, your next meal of corn, or to starve in your beautiful home"; the land "once paved over and built on, it never comes back"; "we're each only here for a few decades, the land is here forever"; this will "destroy the resources of our community and our nation." Some speakers raised the spectre of peak oil and "third world countries like China and pet poisoning", others cautioned that "it will become a sinkhole, the black hole of Calcutta." The interests expressed here are not just parochial. With such emotive and powerful language, it is clear that this is not a small scale local battle; this is about the preservation of a way of life, the prospects for global food security, a global population explosion, the rising geopolitical power of China, the end of oil, and the future of Canada. The corrupt world of capitalist urban development threatens the sanctity of this rural place and the moral community that has charged itself with protecting it. While the issues at stake here are local and immediate, they refer to and reach towards the eternal and universal. Finally, the comment that received the most rapturous applause, and the loudest cheers: "God made the land without the intention to give it to the devil." As Durkheim notes, the reality of collective life is embodied in the opposition between the figure of God and the figure of Satan, and "[i]f the relationship between these forces was reversed, life would be impossible" (EFRL: 423).

This was not to be the last word, but it might as well have been: a moral community had now fully formed around the sanctity of the land, and had committed itself to the salvation of the land from the spectre of an urban-style capitalist development that would contrast so sharply with the community's self-image. In January 2011, a final public hearing on the rezoning ran for six hours and was threaded through with comments like those above. It ended at 11:30 PM and was to be followed the next day by Council's final decision on the rezoning. For this, No Farms No Food held a procession to the Council chambers that they dubbed a "Funeral for Farmland." Those gathered marched slowly and the mood was sombre with some occasional chanting. This strategic pre-emptive commemoration was similar in many ways to the piacular rites described by Durkheim. Such rites are "conducted under conditions of uncertainty or sadness", their purpose to "meet a calamity or to remember or mourn one" (EFRL: 393, 392). While this rite is generally sombre, a "kind of anger is usually mingled with it" (ibid.: 397). Here, individual mourning is less the expression of a personal emotion than it is about that of a broader moral community: "[m]ourning is not the natural response of 
a private sensibility hurt by a cruel loss. It is an obligation imposed by the group. One laments not simply because one is sad but because one is obligated to lament" (ibid.: 400-401).

Through the invocation of the sacred, rites affirm and instantiate collectively held beliefs, demonstrating to individuals that the group is sufficiently powerful to endure individual calamities. Clearly, the imposition of a moral obligation to mourn at the "Funeral for Farmland" is weaker than it is, say, in the actual death of a respected community leader. Nonetheless, the "Funeral for Farmland" was solidarizing, drawing on the powerful symbolism of a piacular rite to emphasize a broader moral claim around what is sacred to the local community. Consequently, the symbolic import of the march transcends its significance as an expression of group solidarity. The fact that it was pre-emptive added to, rather than diminished, its power. Immediately following the "funeral", having consistently voted in favour of the rezoning despite massive local opposition, Council finally voted to reject the application for rezoning. The successful invocation of the sacred has real effects. It reverses political decisions. It turns the world around.

\section{Conclusion}

Nobody has a monopoly on the means of symbolic production in civil society. The binary discourse of civil society has a discernible structure, and is available to individual and collective actors to be used in a variety of ways in an array of contexts. The invocation and use of the sacred/ profane binary cannot be externally proscribed. That it can be used by everyone is not to say that it can be used effectively or successfully by anyone. Effective use demands the capacity to garner moral force to an argument. Success rests upon placing one's own position on the side of the sacred. Those who are successful are those whose meanings stick, at least for a while. Actors might simplify positions, but their actions are by no means simple. While positions are discursively constructed and relative, in practice they are treated as real and absolute (EFRL: 36).

The power to harness particular interpretations - symbolic power - has consequences that are more than symbolic. Power can accrue to those who appear to lay legitimate claim to strong communion with, and the right to use, those symbols in ways that matter. Laying claim to what is sacred and bringing others under the umbrella of shared sacred collective representations gives power to an argument; it moves people (literally and figuratively) less with authority than with influence (Alexander 2006, 70), and influence here is neither the wielding of coercive 
power and authority in a political structural sense, nor is it hegemonic consent (Gramsci 1971). The binary structure of civil discourse requires that actors, activities, relationships and institutions dwell — or are made to dwell, through successful command of the interpretive process - on one side or the other. This discourse is not purely schematic; it is upon the structure of this discourse that "communities build the familiar stories, the rich narrative forms, that guide their everyday, taken-for-granted political life" (Alexander 2006: 60). Symbolic power is moral power, and thus, is a force that consolidates and mobilizes a social bond. Moral power is available to those whose narratives, by virtue of being articulated, compel actors to unify: to be effective, symbolic power must be affective. Discerning what is sacred means finding the one voice that unites the many, or conjuring a harmony from the midst of an apparent cacophony.

We cannot conceive of civil society only in the abstract; we have no empirical access to the world independent of the local realities that we encounter and through which we live our everyday lives. Civil society both inhabits and modifies particular spaces: our embeddedness is local and grounded, social and spatial. That said, local realities are also shaped and infused with a broadened pool of collective representations that come to us through increasingly globalized media and communications. The successful mobilization of the binary discourse demonstrated here rests upon claims to the sanctity of land becoming tethered to claims that are much greater in scope and extent than a few farmers' fields in the immediate locality. At stake are democratic rights, due process in the legal system, protection from global capitalism, our collective destiny and capacity to shape the future.

Durkheim tells us that for those bound by and to a sacred object, criticism, denial or questioning of the sacred is forbidden (EFRL: 215). Before concluding I want to point out the extent to which this conflict in rural Nova Scotia taps into a sacred principle with wider salience in contemporary Canada. In the battle over rezoning, "the local" is a contested and ambiguous terrain, but discursive fixing asserts particular representations of that "local" as sacred. While the rural is at the sacred centre of the local in the case outlined here, more broadly, the local is at the sacred centre of an emergent collective conscience in contemporary Canada, and perhaps beyond.

While there is much that is positive about this, assertions of the sanctity of the local do not mean that all present in a locale are bound in relations of solidarity. Territorial aggregation cannot be confused with moral community and fellow feeling does not automatically flow from contiguity in space. The sanctification of the local brings with it much 
potential and many pitfalls for the expansion of solidarity. As Guthman (2008) has demonstrated, there is a notable discrepancy between the universalizing claims of local food movements, for example, and the range of people who are actually included and involved in these movements. To the fore there must be a deeper understanding of how the sanctification of the local may go hand in hand with retrenchment away from the expanding and ultimately universal solidarity envisaged by Durkheim (1964; EFRL; Inglis \& Robertson 2008).

The case offered here illustrates both a general theory of the connections between symbolic action and collective mobilization, and the relative independence of this relationship from political and economic spheres. It bolsters Durkheim's (1974) claim around the partial autonomy of collective representations from material concerns: those who stood to potentially benefit from the rezoning were not uniformly for or against, those farming in the area for generations were not uniformly for or against, nor were the propertied classes more generally. The conflict cut across political, economic and kinship ties. As Alexander claims, "symbolic boundaries are not isomorphic with political and economic boundaries. The civil sphere is neither the product, nor much less the simple reflection, of purely vertical economic, political, religious, racial, or patriarchal force" (Alexander 2007: 25). The binary code of civil society which organizes public discourse, directs, with great moral force, any discussion of matters where collectively held, deeply felt, and morally influential values - sacred values - are thought to be threatened. From the ubiquitous signs and the range of letters to the editor opposing the rezoning, to the emotive public meetings and the pre-emptive funeral march, a local social movement successfully wielded sufficient symbolic power to shape political decision-making. It did so because a moral community coalesced around a shared conception of the land as sacred. The sacred organizes and orients collective action, and a moral community is in a mutually constitutive relationship with that sacred. This being the case, the only way to develop the Garden of Eden is to make a pact with the Devil.

\section{REFERENCES}

Alexander, Jeffrey C. 2000. Theorizing the good society: hermeneutic, normative and empirical discourses. The Canadian Journal of Sociology 25 (3):271-309. http://www.jstor.org/stable/3341644 2006. The Civil Sphere. Oxford: Oxford University Press. 
. 2007. The meaningful construction of inequality and the struggles against it: a "strong program" approach to how social boundaries change. Cultural Sociology 1(1):23-30. http://cus.sagepub.com/cgi/ $\underline{\text { doi/10.1177/1749975507073915 }}$

Alexander, Jeffrey C. and Philip Smith. 2001. The strong program in cultural sociology: elements of a structural hermeneutics. pp.135-150 in Jonathan H. Turner, ed., The Handbook of Sociological Theory. New York: Kluwer.

Baiocchi, Gianpaolo. 2006. The civilizing force of social movements: corporate and liberal codes in Brazil's public sphere. Sociological Theory 24(4):285-311. http://www.jstor.org/stable/25046727

Bonner, Kieran. 1997. A Great Place to Raise Kids: Interpretation, Science, and the Rural-Urban Debate. Montreal: McGill-Queen's University Press.

Cladis, Mark S. 2005. Beyond solidarity? Durkheim and twenty-first century democracy in a global age. pp. 383-409 in Jeffrey C. Alexander and Philip Smith, ed., The Cambridge Companion to Durkheim. Cambridge: Cambridge University Press.

Corcoran, Mary P. 2010. “God's golden acre for children": pastoralism and sense of place in new suburban communities. Urban Studies 47(12):25372554. http://usj.sagepub.com/cgi/doi/10.1177/0042098009359031

Crowley, Gregory J. 2005. The Politics of Place: Contentious Urban Redevelopment in Pittsburgh. Pittsburgh: University of Pittsburgh Press.

Durkheim, Émile. 1960. Essays on Sociology and Philosophy. Kurt Wolff, ed., New York: Harper \& Row.

. 1964. The Division of Labour in Society. Trans. George Simpson. New York: Free Press.

. 1974. Sociology and Philosophy. Trans. D.F.Pocock. New York: Free Press.

. 1992. Professional Ethics and Civic Morals. Trans. Cornelia Brookfield. London \& New York: Routledge.

. 1995[1912]. The Elementary Forms of Religious Life. Trans. Karen E. Fields. New York: Free Press.

Elkin, Stephen L. 1985. Twentieth century urban regimes. Journal of Urban Affairs 7(2):11-28. http://dx.doi.org/10.1111/j.1467-9906.1985.tb00080.x

Geertz, Clifford. 1973. The Interpretation of Cultures. New York: Basic Books.

Goody, Jack. 1961. Religion and ritual: the definitional problem. British Journal of Sociology 12(2):142-64. http://www.jstor.org/stable/586928

Gramsci, Antonio. 1971. Selections from the Prison Notebooks. New York: International Publishers.

Guthman, Julie. 2008. "If they only knew": color blindness and universalism in California alternative food institutions. The Profession- 
al Geographer 60(3):387-397. http://www.tandfonline.com/doi/ abs/10.1080/00330120802013679.

Habermas, Jürgen. 1996. Between Facts and Norms: Contributions to a Discourse Theory of Law and Democracy. Trans. William Rehg. Cambridge, MA: MIT Press.

Horgan, Mervyn. 2004. Anti-urbanism as a way of life: disdain for Dublin in the nationalist imaginary. Canadian Journal of Irish Studies 30(2):38-47. http://www.jstor.org/stable/25515532

Inglis, David, \& Roland Robertson. 2008. The elementary forms of globality: Durkheim and the emergence and nature of global life. Journal of Classical Sociology 8(1):5 -25. http://jcs.sagepub.com/content/8/1/5.abstract

Jacobs, Ronald N. 2000. Race, Media, and the Crisis of Civil Society: from Watts to Rodney King. Cambridge: Cambridge University Press.

Keohane, Kieran. 1997. Symptoms of Canada: an essay on the Canadian identity. Toronto: University of Toronto Press.

Ku, Agnes. 1999. Narratives, Politics, and the Public Sphere: Struggles Over Political Reform in the Final Transitional Years in Hong Kong (19921994). London: Ashgate.

Lillard, Richard G. 1966. Eden in Jeopardy: Man's Prodigal Meddling with his Environment: The Southern California Experience. Westport, CT: Greenwood.

Logan, Michael F. 1995. Fighting Sprawl and City Hall: Resistance to Urban Growth in the Southwest. Tucson: University of Arizona Press.

Mason, Robert J. 1992. Contested Lands: Conflict and Compromise in New Jersey's Pine Barrens. Philadelphia: Temple University Press.

McKay, Ian. 1994. The Quest of the Folk: Antimodernism and Cultural Selection in Twentieth-Century Nova Scotia. Montreal: McGill-Queen's University Press.

Municipality of the County of Kings. 2010a. Post Public Participation Meeting Report to the Planning Advisory Committee. Sept. 28. .2010b. Report to the Committee of the Whole. Oct. 19.

Pahl, R. E. 1966. The rural-urban continuum. Sociologia Ruralis 6(3):299-329. http://dx.doi.org/10.1111/j.1467-9523.1966.tb00537.x

Perrin, Andrew J., and Stephen Vaisey. 2008. Parallel public spheres: distance and discourse in letters to the editor. American Journal of Sociology 114(3):781-810. http://www.jstor.org/stable/10.1086/590647

Pickering, William S.F. 1984. Durkheim's Sociology of Religion. London: Routledge.

Ramp, William J. 2001. Durkheim and the unthought: some dilemmas of modernity. The Canadian Journal of Sociology / Cahiers Canadiens de Sociologie 26(1):89-115. http://www.jstor.org/stable/3341512 
Reed, Isaac Ariail. 2011. Interpretation and Social Knowledge: On the Use of Theory in the Human Sciences. Chicago \& London: University of Chicago Press.

Riley, Alexander T. 2005. "Renegade Durkheimianism" and the transgressive left sacred. pp.274-301 in Jeffrey C. Alexander and Philip Smith, eds., The Cambridge Companion to Durkheim. Cambridge: Cambridge University Press.

Rome, Adam. 2001. The Bulldozer in the Countryside: Suburban Sprawl and the Rise of American Environmentalism. Cambridge: Cambridge University Press.

Schwartz, Barry. 1991. Mourning and the making of a sacred symbol: Durkheim and the Lincoln assassination. Social Forces 70(2):343-364. http://www. jstor.org/stable/2580243

Sibley, David. 1997. Endangering the sacred: nomads, youth cultures and the English countryside. pp. 218-231 in Paul Cloke \& Jo Little, eds., Contested Countryside Cultures: Otherness, Marginalisation, and Rurality. London: Routledge.

Smith, Neil. 1996. The New Urban Frontier: Gentrification and the Revanchist City. London and New York: Routledge.

Smith, Philip. 2005. Why War? The Cultural Logic of Iraq, The Gulf War and Suez. Chicago: University of Chicago Press.

Tiryakian, Edward A. 1995. Collective effervescence, social change and charisma: Durkheim, Weber and 1989. International Sociology 10 (3): 269 -281. http://iss.sagepub.com/content/10/3/269

Tönnies, Ferdinand. 2002. Community and Society. Trans. Charles P. Loomis. Mineola, NY: Dover Publications.

Weber, Max. 1968. Economy and Society: An Outline of Interpretive Sociology. Guenther Roth and Claus Wittich, eds., Berkeley, CA: University of California Press.

West, Brad, and Philip Smith. 1996. Drought, discourse, and Durkheim: a research note. Journal of Sociology 32(1): 93-102. http://jos.sagepub.com/ cgi/doi/10.1177/144078339603200109

Whyte, William H. 1968. The Last Landscape. New York: Doubleday.

Williams, Raymond. 1985. The Country and the City. London: Hogarth Press.

\section{ACKNOWLedgments}

A draft of this paper was presented at the 2011 meetings of the Canadian Sociological Association in Fredericton. Thanks to Michael Christensen, Saara Liinamaa, Peter Mallory, Marcia Oliver, Steve Tasson, and 
other members of the Canadian Network for Critical Sociology for their thoughtful feedback. Special thanks to Jesse Carlson for many stimulating conversations about Durkheim and cultural sociology. Thanks also to students in my Graduate Seminar in Sociological Theory for their inspired scepticism around cultural sociology, and to Emma Van Rooyen, Aline Nizigama and Quentin Fouville for their part in bringing this project to fruition. Feedback from the editors and two anonymous reviewers strengthened the paper immeasurably.

Mervyn Horgan is an assistant professor in the Department of Sociology and Anthropology at the University of Guelph, and co-convenor of the Canadian Sociological Association's Social Theory Research Cluster. Alongside an engagement with Durkheimian cultural sociology, his current research examines incivilities between strangers, urban public spaces, and the generation, consolidation and dissolution of solidarity in everyday life.

Website: http://www.uoguelph.ca/socioanthro/mervyn-horgan

Email: mhorgan@uoguelph.ca 
764 C CANadian Journal of Sociology/Cahiers Canadiens de SOCiologie 39(4) 2014 